\title{
Wioleta Karwacka
}

Instytut Anglistyki i Amerykanistyki

Uniwersytet Gdański

wioleta.karwacka@ug.edu.pl

\section{WYBRANE CECHY JEZZYKA MEDYCZNEGO \\ - TERMINOLOGIA, NORMALIZACJA, GATUNKI TEKSTÓW MEDYCZNYCH I RELACJE MIĘDZYGATUNKOWE}

Trudno sformułować zbiór cech ogólnych języka medycznego - nie tylko ze względu na wielość poszczególnych języków etnicznych, w ramach których rozwija się polilekt medyczny, ale też na znaczne zróżnicowanie gatunków tekstów charakterystycznych dla komunikacji w środowisku związanym $\mathrm{z}$ medycyną i służbą zdrowia. W języku medycznym są bowiem napisane podręczniki akademickie dla studentów medycyny, ulotki do leków, dokumentacja szpitalna, opis dołączony do zdjęcia rentgenowskiego, czy publikacja noblisty Gregga L. Semanzy w czasopiśmie „Science”. Język, który stosowany jest w społeczności związanej ze służbą zdrowia, obejmującej m.in. lekarzy, pacjentów, naukowców czy tłumaczy pośredniczących w ich komunikacji, ma jednak pewne wspólne cechy.

W warstwie leksykalnej szczególną uwagę zwraca nomenklatura medyczna z terminami wielowyrazowymi, skrótami i skrótowcami, obecność łacińskich i greckich rdzeni, przedrostków i przyrostków, zapożyczeń, a także hiperoi hiponimicznych relacji między pojęciami (od nazw ogólnych po szczegółowe i odwrotnie, np. w języku angielskim condition - allergy - hay fever) (zob. Mićić 2013: 221-223). Do charakterystycznych cech pragmatycznych widocznych w języku medycznym należą m.in. bezosobowość, zwięzłość oraz stosowanie żargonu, przy czym poszczególne gatunki tekstów medycznych (np. ulotka dla pacjenta, charakterystyka produktu leczniczego, zgoda pacjenta, karta informacyjna leczenia szpitalnego, artykuł medyczny, opis badania USG) podlegają określonym konwencjom (zob. Fløttum 2006; Mićić 2013; Kościałkowska-Okońska 2018). Przykładowo zgoda pacjenta i ulotka to teksty pisane językiem mało specjalistycznym, zawierające istotne dla pacjentów informacje 
przekazane w możliwie przystępny sposób. Z kolei w dokumentacji szpitalnej znajdziemy teksty o dużym nasyceniu specjalistyczną terminologią, które zawierają szczegółowe informacje dotyczące leczenia pacjenta sformułowane bardzo zwięźle, wręcz kompaktowo, a przy tym - bezosobowo.

W niniejszym tekście omówione zostaną wybrane cechy języka medycznego: terminologia, a szczególnie wpływy greckie i łacińskie, eponimy, skróty i terminy wielowyrazowe, kontrolowane terminologie, gatunki tekstów medycznych oraz łączące je relacje międzygatunkowe. Przykłady przytoczone w tekście pochodzą z języka angielskiego i polskiego.

\section{Terminologia medyczna}

Salager-Meyer (1983) wprowadza następujący podział terminów (słów) i wyrażeń angielskiego języka medycznego w zależności od ich zasięgu: 1) BE (basic English) - język angielski wspólny dla wszystkich rodzajów tekstów, 2) FME (fundamental medical English) - podstawowy angielski język medyczny charakteryzujący się niemal równomiernym występowaniem w całym języku medycznym oraz 3) SME (specialized medical English) - obejmujący terminy specjalistyczne specyficzne dla danej dyscypliny. Podobny podział możemy zastosować w obrębie innych języków etnicznych.

Podstawowy medyczny język angielski charakteryzuje się występowaniem trzech zjawisk językowych:

1) rzeczowników złożonych, np. contrast medium („środek kontrastujący”), heart failure („niewydolność krążenia”);

2) afiksacji, np. fail - failure - failed, ventricle - ventricular - supraventricular;

3) dubletów - rdzenie z kategorii FME mają pochodzenie łacińskie i posiadają swoje semantyczne odpowiedniki w BE i języku ogólnonaukowym (odpowiednio: investigate - search, produce - yield, obtain - have, initiate - begin, remain - be left) (Salager-Meyer 1983: 61-62).

Dublety są także zauważalne $\mathrm{w}$ rdzeniach przymiotników, szczególnie $\mathrm{w}$ porównaniu do rzeczowników (np. kidney function - renal function, heart failure - cardiac failure, Salager-Meyer 1983: 62).

Kolejną cechą języka medycznego jest jego metaforyczność, choć wydawałoby się, że jako język specjalistyczny nie odznacza się figuratywnością. Jedna z dominujących metafor pojęciowych w języku medycznym to MEDYCYNA TO WOJNA (Tajer 2012; Mićić 2013; Navarro, Ferrando 2016; Domínguez, Sapiña 2016).

Warto także pamiętać, że z jednej strony w polszczyźnie potocznej występują sformułowania uznawane za niepoprawne w specjalistycznym języku medycznym, np. „poziom cukru” („stężenie glukozy”), „symptom” („objaw”), „woreczek żółciowy” („pęcherzyk żółciowy”), z drugiej zaś - w żargonie lekarskim zdarzają się także określenia, które nie są zgodne z regułami poprawności 
np. „zrobić tomokomputer” („wykonać tomografię komputerową”). Terminy medyczne (np. „zraziki wątroby”, „płatki zastawki”, „łodygi włosów”, „lejki mieszków włosowych") mogą zawierać elementy z rejestru ogólnego oraz elementy polisemiczne lub metaforyczne (zob. Karwacka 2016).

\section{Wpływy lacińskie i greckie na terminologię medyczną}

Wplywy laciny i greki obserwowane w dubletach BE - FME oraz rdzenie, przyrostki i przedrostki pochodzące z tych języków to typowe cechy terminologii medycznej. W polskim języku medycznym dublety stosowane są wówczas, gdy autor chce zaznaczyć istnienie więcej niż jednej nazwy, np. pisząc „nazywany również...” (zob. Górnicz 2003: 111-112).

Dawniej to łacina była lingua franca medycyny, choć wiele odkryć zostało po raz pierwszy opisanych $w$ innych językach, m.in. w języku arabskim, a dopiero później w przekładach tłumaczy z Toledo na łacinę. Znaczenie stopniowo zmniejszało się, a w XX wieku to angielski stał się dominującym językiem międzynarodowej komunikacji między badaczami nauk medycznych. Do dziś jednak obserwujemy w terminologii medycznej silnie zaznaczone wpływy łaciny oraz greki i - choć zakres tych wpływów nie jest taki sam we wszystkich językach etnicznych - obserwujemy je np. w przedrostkach i przyrostkach:

- adipo - „tluszcz”, np. „adipokiny” (PL), adipokine, adipocytokines (EN);

- kranio/cranio - „czaszka”, np. „kraniotomia” (PL), craniotomy (EN);

- onko/onco - związany z nowotworem, np. „onkologia” (PL), oncology (EN);

- algia - ból, np. „neuralgia” (PL, EN);

- lepsja/lepsy - „napad”, np. „epilepsja” (PL), epilepsy (EN);

- otomia/otomy - „przecięcie”, np. „kraniotomia” (PL), craniotomy (EN).

Kolejna charakterystyczna cecha angielskiego języka medycznego, o której była mowa wyżej, to dublety - pary np. rzeczowników często wywodzących się z języka anglosaskiego i występujących we współczesnym języku ogólnym oraz przymiotników bezpośrednio pochodzących z łaciny lub greki:

Tabela 1. Dublety - pary rzeczowników i przymiotników

\begin{tabular}{|c|c|}
\hline Rzeczownik & Przymiotnik \\
\hline 1 & 2 \\
\hline bone & osseous (lac.) \\
\hline eye & optic (lac.) \\
\hline liver & hepatic (gr.) \\
\hline
\end{tabular}


Tabela 1 (cd.)

\begin{tabular}{|c|c|}
\hline 1 & 2 \\
\hline fat & adipose (łac.) \\
\hline neck & cervical (łac.) \\
\hline backbone & spinal (łac.) \\
\hline kidney & renal (łac.) \\
\hline stomach & gastric (gr.) \\
\hline navel & umbilical cord (łac.) \\
\hline mouth & oral (łac.) \\
\hline windpipe & tracheal (łac.) \\
\hline ear & auditory (łac.) \\
\hline breast & mammary (łac.) \\
\hline lungs & pulmonary (łac.) \\
\hline teeth & dental (łac.) \\
\hline heart & cardiac (gr.) \\
\hline brain & cerebral (łac.) \\
\hline
\end{tabular}

Źródło: opracowano na podstawie: Polackova 2006: 131; zob. Salager-Meyer 1983; Karwacka 2015.

Terminologia w rozmaitych językach różni się pod względem zasięgu wpływów łacińskich i greckich. Zjawisko to można obserwować także - choć w znacznie mniejszym stopniu niż w angielskim języku medycznym - w języku polskim:

Tabela 2. Przykłady wpływów greckich i łacińskich na terminy medyczne w języku polskim

\begin{tabular}{|c|c|}
\hline Narząd & Gałąź medycyny \\
\hline ptuca & pulmonologia (łac., gr.) \\
\hline serce & kardiologia (gr.) \\
\hline watroba & hepatologia (gr.) \\
\hline żołąek & gastrologia (gr.) \\
\hline
\end{tabular}

Źródło: opracowanie własne ${ }^{1}$.

1 Tabele 2, 3, 4 i 5 to opracowania własne na podstawie słowników: Elsevier's Dictionary of Medicine and Biology: In English, Greek, German, Italian and Latin, Dorland's 
Tabele 3 i 4 zawierają przykłady podobieństw i różnic związanych z przedrostkami i przyrostkami stosowanymi w polskim i angielskim języku medycznym.

Tabela 3. Przedrostki i przyrostki w języku medycznym

\begin{tabular}{|c|c|c|c|c|}
\hline Prefiks/Sufiks & Znaczenie & $\begin{array}{c}\text { Przykłady } \\
\text { występowania } \\
\text { wj.polskim }\end{array}$ & $\begin{array}{l}\text { Przykłady wy- } \\
\text { stępowania wj. } \\
\text { angielskim }\end{array}$ & Znaczenie \\
\hline \multirow{4}{*}{$\begin{array}{l}\text { Prefiks: hipo-/ } \\
\text { hypo- (gr. טّँo-) }\end{array}$} & \multirow{4}{*}{$\begin{array}{l}\text { Zbyt mały/ } \\
\text { zbyt niski }\end{array}$} & hipotermia & hypothermia & $\begin{array}{l}\text { zbyt niska } \\
\text { temperatura } \\
\text { ciała }\end{array}$ \\
\hline & & hipoglikemia & hypoglyc(a)emia & $\begin{array}{l}\text { zbyt małe } \\
\text { stężenie glukozy }\end{array}$ \\
\hline & & hipokalcemia & hypocalc(a)emia & $\begin{array}{l}\text { zbyt małe } \\
\text { stężenie wapnia } \\
\text { w surowicy }\end{array}$ \\
\hline & & hipotermia & hypothermia & $\begin{array}{l}\text { wychłodzenie } \\
\text { organizmu }\end{array}$ \\
\hline \multirow{4}{*}{ 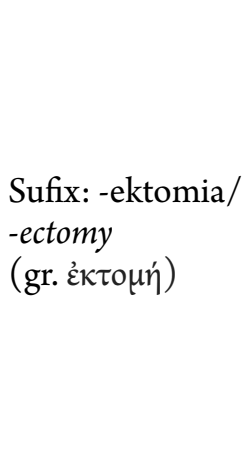 } & \multirow{4}{*}{ usunięcie } & mastektomia & mastectomy & usunięcie piersi \\
\hline & & $\begin{array}{l}\text { apendekto- } \\
\text { mia/ usunięcie } \\
\text { wyrostka } \\
\text { robaczkowego }\end{array}$ & appendectomy & $\begin{array}{l}\text { usunięcie } \\
\text { wyrostka } \\
\text { robaczkowego }\end{array}$ \\
\hline & & gastrektomia & gastrectomy & \begin{tabular}{|l} 
usunięcie \\
żołądka
\end{tabular} \\
\hline & & lobektomia & lobectomy & $\begin{array}{l}\text { usunięcie płata } \\
\text { narządu }\end{array}$ \\
\hline
\end{tabular}

Źródło: opracowanie własne.

Illustrated Medical Dictionary, Dorland Medyczny stownik angielsko-polski, polsko-angielski, Podręczny stownik medyczny tacińsko-polski i polsko-łaciński, Podręczny stownik medyczny angielsko-polski i polsko-angielski. 
Tabela 4. Terminy z sufiksem -itis w języku angielskim i odpowiadające im terminy wielowyrazowe w języku polskim

\begin{tabular}{|c|c|c|c|}
\hline Sufiks & Znaczenie & $\begin{array}{l}\text { Termin w jezzyku } \\
\text { angielskim }\end{array}$ & $\begin{array}{l}\text { Termin w języku } \\
\text { polskim }\end{array}$ \\
\hline \multirow{4}{*}{$\begin{array}{l}\text {-itis (lac. -tis, } \\
\text { gr. -iٓıৎ) }\end{array}$} & \multirow{4}{*}{ zapalenie } & bronchitis & zapalenie oskrzeli \\
\hline & & dermatitis & zapalenie skóry \\
\hline & & gastritis & $\begin{array}{l}\text { zapalenie błony } \\
\text { śluzowej żołądka }\end{array}$ \\
\hline & & hepatitis & zapalenie wątroby \\
\hline
\end{tabular}

Źródło: opracowanie własne.

Często w języku polskim obserwujemy terminy wielowyrazowe, opisowe, odpowiadające terminom angielskim utworzonym z prefiksów, rdzeni i sufiksów greckich lub łacińskich, np. cholecystectomy (EN) - „usunięcie pęcherzyka żółciowego” (PL), rhabdomyosarcoma (RMS) (EN) - „mięsak prążkowanokomórkowy” (PL).

We współczesnym języku medycznym łacińskie i greckie elementy stosowane są nie zawsze konsekwentnie (zob. McMorrow 1998: 21), czego wynikiem są hybrydy powstałe $\mathrm{z}$ połączenia np. greckich prefiksów i łacińskich rdzeni, jak w wyrazach „dysfunkcja” (dysfunction), czy „liposukcja” (liposuction). Łacina i greka stanowią fundament także najnowszej nomenklatury medycznej (np. orthohantavirus, coronavirus). Trzeba jednak przyznać, że to angielski język medyczny pośredniczy w rozprzestrzenianiu się wpływów tych dwóch języków starożytnych.

\section{Eponimy}

Spory udział w nomenklaturze medycznej mają eponimy, czyli określenia utworzone od nazw własnych, np. nazwisk badaczy („choroba Parkinsona”, „zespół Downa”), miejsc („wirus Zika”), postaci mitycznych („zespół Otella”). Eponimami mogą być nie tylko nazwy chorób, lecz także nazwy objawów („objaw Babińskiego”), złamań („złamanie zgięciowe typu Messerera”), zabiegów („operacja Belseya”), narzędzi chirurgicznych („kleszczyki Babcocka”), struktur anatomicznych („,́sięgno Achillesa”) itd. (Karwacka 2015).

Dla użytkowników języka medycznego istotne jest to, że eponimy mogą mieć zasięg międzynarodowy lub nie. Zatem eponim w jednym języku może mieć 
nieeponimiczne odpowiedniki w innych językach lub występować w nich pod innym eponimem. Zdarza się też, że w jednym języku mamy do czynienia z eponimem i synonimicznym terminem opisowym nierzadko wypierającym eponim.

Tabela 5. Przykłady eponimów w języku polskim i angielskim

\begin{tabular}{|c|c|c|c|}
\hline Angielski eponim & $\begin{array}{l}\text { Angielski termin } \\
\text { opisowy }\end{array}$ & Polski eponim & $\begin{array}{l}\text { Polski termin } \\
\text { opisowy }\end{array}$ \\
\hline $\begin{array}{l}\text { Giardia lamblia } \\
\text { Giardia duodenalis } \\
\text { Giardia intestinalis }\end{array}$ & & $\begin{array}{l}\text { Giardia lamblia } \\
\text { Lamblia jelitowa }\end{array}$ & $\begin{array}{l}\text { ogoniastek jelitowy } \\
\text { wielkouściec } \\
\text { jelitowy }\end{array}$ \\
\hline Cowper's glands & $\begin{array}{l}\text { bulbouretheral } \\
\text { glands }\end{array}$ & & $\begin{array}{l}\text { gruczoły } \\
\text { opuszkowo- } \\
\text {-cewkowe }\end{array}$ \\
\hline Bartholin glands & $\begin{array}{l}\text { greater vestibular } \\
\text { glands }\end{array}$ & & $\begin{array}{l}\text { gruczoły } \\
\text { przedsionkowe } \\
\text { większe }\end{array}$ \\
\hline Lyme disease & & & borelioza \\
\hline \multirow[t]{3}{*}{ Fallopian tube } & & & jajowód \\
\hline & reflexlocomotion & metoda Vojty & \\
\hline & $\begin{array}{l}\text { erythrocyte } \\
\text { sedimentation rate } \\
\text { (ESR) }\end{array}$ & $\begin{array}{l}\text { odczyn } \\
\text { Biernackiego (OB) }\end{array}$ & \\
\hline Crohn disease & & $\begin{array}{l}\text { choroba } \\
\text { Leśniowskiego- } \\
\text {-Crohna }\end{array}$ & \\
\hline
\end{tabular}

Źródło: opracowanie własne.

Niektóre eponimy są wypierane przez terminy opisowe wskazujące na charakter lub pochodzenie choroby. Dotyczy to m.in. eponimów utworzonych od nazwisk lekarzy, którzy byli zbrodniarzami wojennymi w czasie II wojny światowej. Obecnie stosuje się np. nazwę „reaktywne zapalenie stawów” zamiast terminu „zespół Reitera” (Reiter's syndrome) (zob. Lu 2005) - jest to międzynarodowy trend, który nie objął jednak jeszcze wszystkich kontrowersyjnych 
eponimów, np. zjawisko „neurodegeneracji związanej z kinazą pantotenianu” nadal figuruje pod eponimem Hallervorden-Spatz disease (choroba Hallervordena-Spatza) w klasyfikacji ICD-10 (zob. Kondziella 2009).

\section{Skróty i skrótowce}

Kolejną cechą języka medycznego jest występowanie terminów wielowyrazowych (np. „paciorkowcowe zapalenie gardła”, streptococcal pharyngitis), w tym również - skracanych do jednostek brachygraficznych (np. COPD - chronic obstructive pulmonary disease, POChP - „przewlekła obturacyjna choroba płuc”, pRBC - packed red blood cells, $\mathrm{KKCz}$ - „koncentrat krwinek czerwonych”, CNS - central nervous system, OUN - „ośrodkowy układ nerwowy”). W polskim języku medycznym zauważyć można tendencję do stosowania angielskich skrótów i skrótowców, np. AIDS, MCV, MCH, fMRI, WBC, RBC, TSH, INR, LDL, HDL itd. (zob. Badziński 2018: 69-70).

\section{Język medyczny jako język kontrolowany}

Inną wyraźną i charakterystyczną tendencją jest dążenie do porządkowania, uniformizacji i normalizacji terminologii, co ma służyć konsekwentnemu stosowaniu nomenklatury i zapewnieniu precyzji w komunikacji między specjalistami. Na przykład nomina anatomica to lista standardowo stosowanych terminów anatomicznych, SNOMED - system nomenklatury medycznej (ilustracja 1), ICD

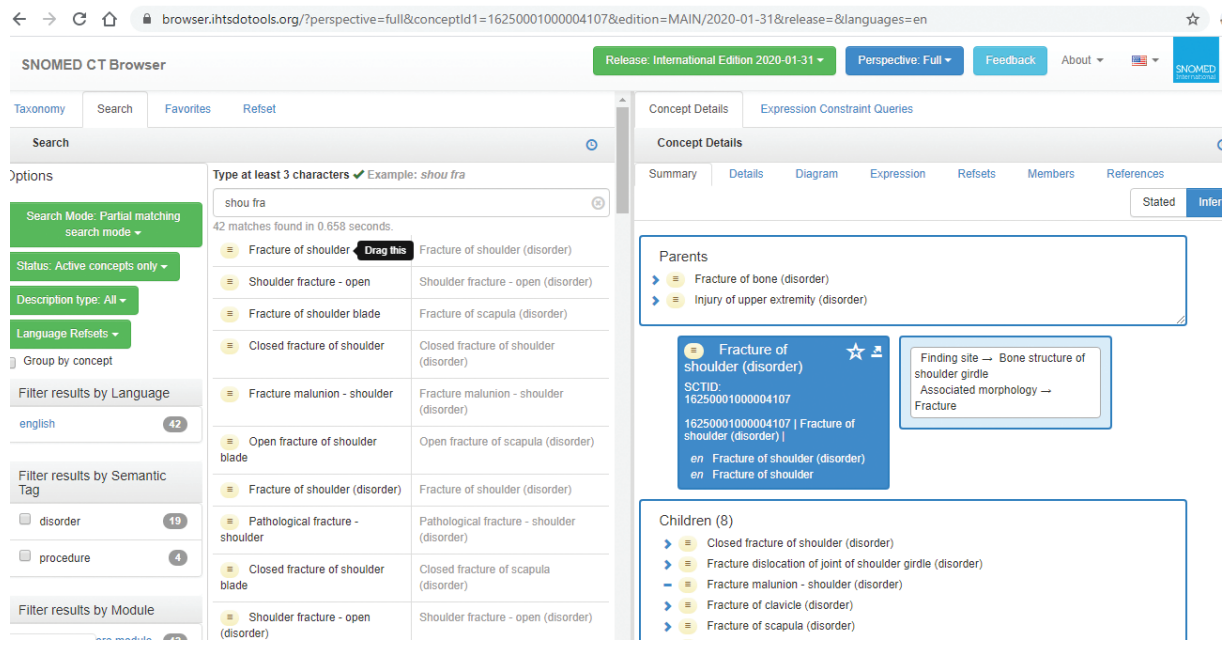

Ilustracja 1. Wygląd wyszukiwarki SNOMED

Źródło: https://browser.ihtsdotools.org/ (dostęp: 26.07.2020). 
- klasyfikacja chorób i problemów zdrowotnych WHO (ilustracja 2), ICF - klasyfikacja funkcjonowania, niepełnosprawności i zdrowia, ICNP - klasyfikacja pielęgniarska (ilustracja 3) itp. Systemy i klasyfikacje to terminologie kontrolowane,

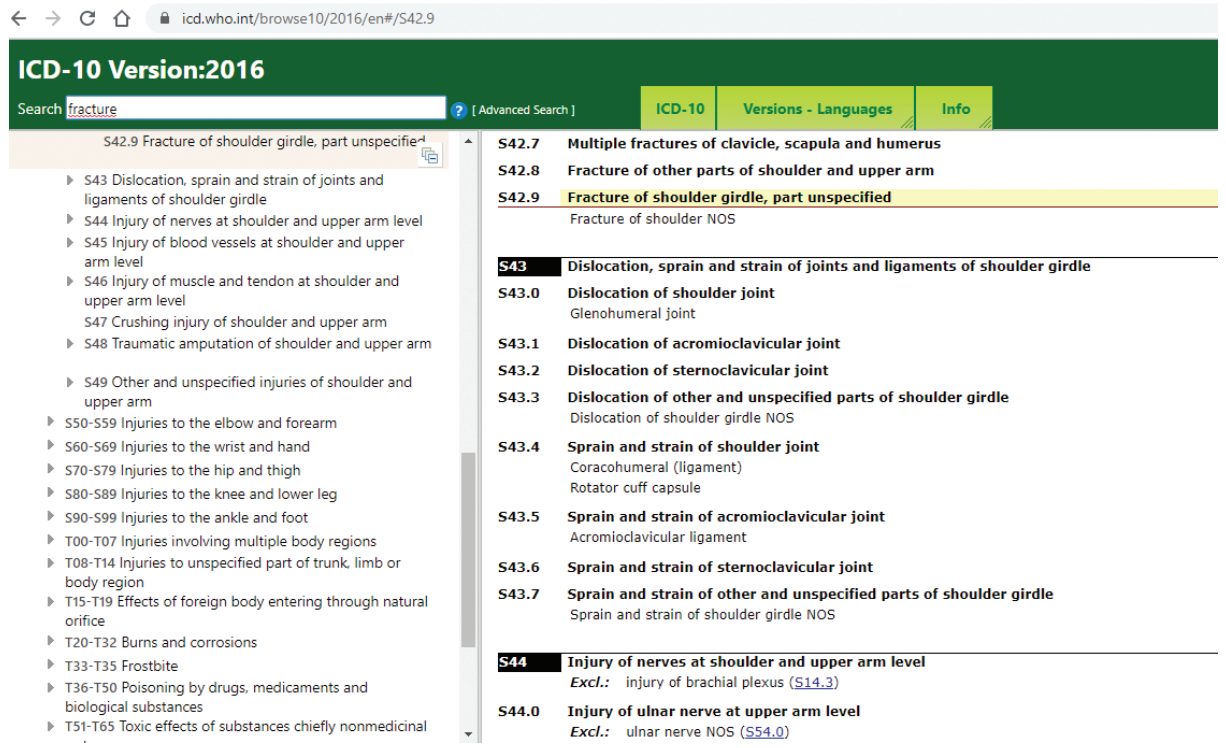

Ilustracja 2. Widok wyszukiwarki ICD

Źródło: https://icd.who.int/browse10/2016/en (dostęp: 26.07.2020).

\section{ICNP Browser}

\section{Przeglądarka Internetowa ICNP 2019 release- Polish- Widok-}

\begin{tabular}{|c|c|c|}
\hline Pobierz... & Typ: & ICNP Primitive \\
\hline ból brzucha & Kod: & 10043948 \\
\hline ból brzucha & Preferowany & ból brzucha \\
\hline ból chroniczny & Termin: & \\
\hline ból fantomowy & Knowledge & AbdominalPain \\
\hline ból fantomowy & Name: & \\
\hline ból kości & Opis: & ból \\
\hline $\begin{array}{l}\text { bol mięsnı } \\
\text { ból mięśniowo-szkieletowy }\end{array}$ & oś: & Przedmiot \\
\hline ból naczyniowy & Rodzic: & böl \\
\hline ból neurogenny & & \\
\hline ból niedokrwienny & Dzieci: & ból brzucha \\
\hline $\begin{array}{l}\text { ból nowotworowy } \\
\text { ból piersi }\end{array}$ & $\begin{array}{l}\text { Po raz } \\
\text { pierwszy: }\end{array}$ & 2015 \\
\hline
\end{tabular}

Ilustracja 3. Widok przeglądarki ICNP

Źródło: https://www.icn.ch/what-we-do/projects/ehealth/icnp-browser

(dostęp: 26.07.2020). 
podlegające rygorystycznej weryfikacji pod kątem jednoznaczności, monoreferencyjności, precyzji i przejrzystości (zob. Karwacka 2016). Trzeba jednak zaznaczyć, że język medycyny nie jest wolny od synonimów (np. tych w tabeli 5) czy wyrazów polisemicznych (zob. Soubrier 2002).

\section{Gatunki tekstów medycznych}

Teksty medyczne tworzą swoistą sieć gatunków i metagatunków powiązanych tematyką i zawartością informacyjną (Piorno 2012: 168), np. w ulotce dla pacjenta znajdziemy informacje opracowane na podstawie obszernego i szczegółowego dokumentu „charakterystyka produktu leczniczego”, choć ten pierwszy dokument powinien być napisany przystępniejszym językiem. Tekst ulotki jest zatem uproszczony zarówno pod względem całościowej budowy tekstu, jak i konstrukcji poszczególnych zdań. Jest bardziej syntetyczny i zawiera tylko te informacje, które są istotne dla pacjenta (np. działania niepożądane, interakcje $\mathrm{z}$ innymi lekami itp.). Tekst jest bardziej bezpośrednio skierowany do odbiorcy. Zamiast terminów specjalistycznych powinny w nim występować określenia opisowe, zrozumiałe dla pacjentów (Piorno 2012: 176). Należy tu jednak zauważyć, że ulotki nie zawsze spełniają postulat czytelności, zawarty między innymi w Dyrektywie 2004/27/ EC (Kościałkowska-Okońska 2018). Postulat ten wynika z trendu umieszczającego pacjenta w centrum uwagi służby zdrowia, a wspomniana Dyrektywa zawiera rekomendację takiego redagowania informacji dla pacjentów, aby były czytelne, klarowne oraz dostępne także dla osób niewidzących. Warto zaznaczyć, że ulotka dla pacjenta powstaje na podstawie charakterystyki produktu i jest następnie tłumaczona na języki unijne. Jest testowana pod kątem czytelności, lecz tylko w oryginale i jednym z języków, na który została przetłumaczona. W tabeli (zob. Kościałkowska-Okońska 2018: 149) przedstawiono fragment ulotki, w którym widać powiązania międzygatunkowe, uproszczenia w ulotce (np. przeciwwskazania - kiedy nie stosować), ale też miejsca, które mogłyby zostać bardziej uproszczone (np. kwasu acetylosalicylowego lub innych podobnych leków przeciwbólowych - NLPZ).

Relacje międzygatunkowe dostrzegamy także między artykułami naukowymi a materiałami popularyzatorskimi. Te pierwsze opisują wyniki badań naukowych prowadzonych zgodnie z rygorami medycyny opartej na dowodach naukowych (evidence-based medicine, EBM), a ich treść zorganizowana jest w konwencji IMRAD, czyli wstęp (introduction), metody (method), wyniki (results), dyskusja (discussion). Teksty popularyzatorskie opracowane na podstawie artykułów naukowych przekazują informacje na ten sam temat, lecz mają 
uproszczoną postać - począwszy od tytułu, przez skrócony, zsyntetyzowany tekst o układzie sprzyjającym łatwemu przyswojeniu informacji, uproszczone - jak w ulotce do leku - zdania napisane w stronie czynnej i bezpośrednio skierowane do odbiorcy, zastąpienie pojęć abstrakcyjnych nieabstrakcyjnymi, aż po determinologizację, czyli opisowe przedstawienie tych pojęć, bez użycia specjalistycznej nomenklatury (Muñoz-Miquel 2012: 169-170).

Tabela 6. Relacje międzygatunkowe na podstawie ulotki dla pacjenta i charakterystyki produktu leczniczego

\begin{tabular}{|c|c|c|c|}
\hline $\begin{array}{l}\text { Patient Information } \\
\text { Leaflet/PIL (EN) }\end{array}$ & $\begin{array}{c}\text { Summary } \\
\text { of Product } \\
\text { Characteristics/ } \\
\text { SPC (EN) }\end{array}$ & \begin{tabular}{|} 
Patient Information \\
Leaflet/PIL \\
(Ulotka dla \\
pacjenta/Ul) (PL)
\end{tabular} & $\begin{array}{l}\text { Summary of Product } \\
\text { Characteristics/SPC } \\
\text { (Charakterystyka } \\
\text { Produktu } \\
\text { Leczniczego/ChPL) } \\
\text { (PL) }\end{array}$ \\
\hline $\begin{array}{l}\text { Do not take Nuro- } \\
\text { fen Express } \\
200 \text { mg liquid cap- } \\
\text { sules if you: } \\
\text { - have had } \\
\text { a worsening of } \\
\text { asthma, skin rash, } \\
\text { itchy runny nose or } \\
\text { facial swelling when } \\
\text { previously taking } \\
\text { ibuprofen, aspirin } \\
\text { or similar medi- } \\
\text { cines }\end{array}$ & $\begin{array}{l}\text { Contraindica- } \\
\text { tions: } \\
\\
\text { Patients who have } \\
\text { previously shown } \\
\text { hypersensitivity } \\
\text { reactions } \\
\text { (e.g. asthma, rhi- } \\
\text { nitis, angioedema, } \\
\text { or urticaria) in } \\
\text { response to aspirin } \\
\text { or other non- } \\
\text { steroidal anti- } \\
\text { inflammatory } \\
\text { drugs (NSAIDs). }\end{array}$ & \begin{tabular}{|l|} 
Kiedy nie \\
stosować leku \\
Nurofen Express: \\
\\
- jeśli u pacjenta \\
kiedykolwiek \\
występowały \\
duszność, astma, \\
nieżyt nosa, obrzęk \\
lub pokrzywka po \\
przyjęciu kwasu \\
acetylosalicylo- \\
wego lub innych \\
podobnych leków \\
przeciwbólowych \\
(NLPZ)
\end{tabular} & $\begin{array}{l}\text { - u pacjentów } \\
\text { z reakcjami nad- } \\
\text { wrażliwości w wy- } \\
\text { wiadzie (np. skurcz } \\
\text { oskrzeli, astma, } \\
\text { zapalenie błony ślu- } \\
\text { zowej nosa, obrzęk } \\
\text { naczynioruchowy } \\
\text { lub pokrzywka) zwią- } \\
\text { zanymi z przyjęciem } \\
\text { kwasu acetylosa- } \\
\text { licylowego (ASA) } \\
\text { lub innych nieste- } \\
\text { roidowych leków } \\
\text { przeciwzapalnych } \\
\text { (NLPZ) }\end{array}$ \\
\hline
\end{tabular}

Źródło: Kościałkowska-Okońska 2018: 149 (wyróżnienia - WK). 


\section{Wnioski}

Przedstawione $\mathrm{w}$ niniejszym artykule cechy to tylko wybrane aspekty bogatego języka medycyny. Język medyczny jest niewątpliwie interesujący ze względu na terminologię, będącą nie tylko precyzyjnym narzędziem komunikacji w środowisku medycznym, lecz także zapisem dziejów medycyny. Język ten wciąż ewoluuje, częściowo w sposób kontrolowany poprzez klasyfikacje będące bazami terminologicznymi, a także regulacje prawne, którym podlegają niektóre gatunki medyczne, np. związane z rejestracją leków. Przyszłość języka medycyny będzie łączyć się z kierunkiem odkryć naukowych i rozwoju techniki, która pośrednio wpływa na stosowanie języka, np. w cyfrowych bazach danych.

\section{Bibliografia}

Badziński A. (2018), Collocations, equivalence and untranslatability as selected critical aspects in medical translation, [w:] Towards Understanding Medical Translation and Interpreting, Gdańsk, s. 67-83.

Domínguez M., Sapiña L. (2016), Cancer Metaphors in Sports News: The match that must be won, [w:] P. Ordonez-Lopez, N. Edo-Marza (red.), Medical Discourse in Professional, Academic and Popular Settings (Language at Work), Bristol-Buffalo-Toronto, s. 149-172.

Dorland W.A.N. (2012), Dorland's Illustrated Medical Dictionary. 32nd edition, Philadelphia.

Dorland W.A.N (2012), Medyczny stownik angielsko-polski, polsko-angielski, wydanie 28, tłum. M. Czarnecki, K. Fleischer, Wrocław.

Dąbrowska B. (1997/2005), Podręczny stownik medyczny tacińsko-polski i polsko-łaciński, Warszawa.

Ezpeleta Piorno P. (2012), An example of genre shift in the medicinal product information genre system, „Linguistica Antverpiensia. New Series”, 11, „Themes in translation Studies", Amberes, s. 139-159, https://lans-tts.uantwerpen. be/index.php/LANS-TTS/article/view/302 (dostęp: 14.02.2020).

Górnicz M. (2003), Terminologia tekstów specjalistycznych, [w:] B.Z. Kielar, S. Grucza (red.), Lingwistyczna identyfikacja tekstów specjalistycznych, Warszawa, s. 106-117.

Fløttum K. (2006), Medical research articles in the comparative perspectives of discipline and language, [w: ] M. Gotti, F. Salager-Meyer (red.), Advances in Medical Discourse Analysis: Oral and Written Contexts, Bern.

Karwacka W. (2015), Medical Translation, [w:] Ł. Bogucki, S. Goźdź-Roszkowski, P. Stalmaszczyk (red.), Ways to Translation, Łódź, s. 271-298. 
Karwacka W. (2016), Przekład tekstów medycznych, Gdańsk.

Kondziella D. (2009), Thirty neurological eponyms associated with the Nazi era, „European Neurology”, t. 62, s. 56-64.

Konstantinidis G. (2006), Elsevier's Dictionary of Medicine and Biology: In English, Greek, German, Italian and Latin, Amsterdam.

Kościałkowska-Okońska E. (2018), Translating patient information leaflets: expectations of users and the reality, [w:] W. Karwacka (red.) Towards Understanding Medical Translation and Interpreting, Gdańsk, s. 137-159, https:// wyd.ug.edu.pl/sites/default/files/_nodes/publikacja/85696/files/ karwacka_-_towards_understanding.pdf (dostęp: 01.05.2020).

Lu D. W. i in. (2005), Declining use of the eponym "Reiter's syndrome” in the medical literature, 1998-2003, "Journal of the American Academy of Dermatology", t. 53(4), s. 720-723.

McMorrow L. (1998), Breaking the Greco-Roman Mold in medical writing: the many languages of $20^{\text {th }}$ century medicine, [w: ] H. Fischbach (red.), Translation and medicine, Amsterdam-Philadelphia, s. 13-28.

Mićić S. (2013), Language of medicine - present and future, "JAHR - Annual of the Department of Social Sciences and Medical Humanities", t. 4(7), s. 217-233, https://www.jahr-bioethics-journal.com/index.php/JAHR/ article/view/87 (dostęp: 14.02.2020).

Muñoz Miquel A. (2012), From the original article to the summary for patients: reformulation procedures in intralingual translation, „Linguistica Antverpiensia NS”, s. 153-162, https://lans-tts.uantwerpen.be/index.php/LANS-TTS/ article/view/303 (dostęp: 14.02.2020).

Navarro i Fernando I. (2017), Conceptual metaphor types in oncology: cognitive and communicative functions, „Ibérica”, nr 34, s. 163-186, https://www. redalyc.org/pdf/2870/287053467008.pdf (dostęp: 10.02.2020).

Polackova G. (2006), The "false friendship" of some medical terms in English-Slovak and Slovak-English translation, „Bratislavské lekárske listy”, nr 107(4), s. $130-131$.

Salager-Meyer F. (1983), The lexis of fundamental medical English: Classificatory framework and rhetorical function (a statistical approach), „Reading in a Foreign Language", t. 1(1), s. 54-64.

Soubrier J. (2002), Les risques du métier à tennis elbow ou épicondylite latérale, „Traduire”, nr 194, s. 55-76.

Słomski P., Słomski P. (1996/2005), Podręczny słownik medyczny angielsko-polski i polsko-angielski, Warszawa.

Tajer C. (2012), Thinking medicine metaphorically, „Argentine Journal of Cardiology", t. 80(6), https://www.sac.org.ar/wp-content/uploads/2014/ 04/2977.pdf (dostęp: 10.02.2020). 


\section{Strony www}

WHO - World Health Organization, ICD-10 Version 2016, https://icd.who. int/browse10/2016/en (dostęp: 24.08.2020).

ICN - International Council of Nurses. 2020. ICNP Browser, https://www.icn. ch/what-we-do/projects/ehealth/icnp-browser (dostęp: 24.08.2020).

SNOMED International Browser, https://browser.ihtsdotools.org/ (dostęp: 24.08.2020).

Wioleta Karwacka

\section{SELECTED FEATURES OF THE MEDICAL LANGAUGE - TERMINOLOGY, STANDARDIZATION, MEDICAL GENRES AND GENRE SHIFT}

(Summary)

This article discusses selected features of the medical language with special emphasis on Polish and English. The first discussed feature is medical terminology, in particular: Greek and Latin influences, eponyms and acronyms. The medical language is a controlled one, which is another aspect presented in this article. The next characteristic feature includes conventions related to particular medical genres. Finally, genre shift is briefly discussed.

Key words: medical language, medical terminology, genre shift 